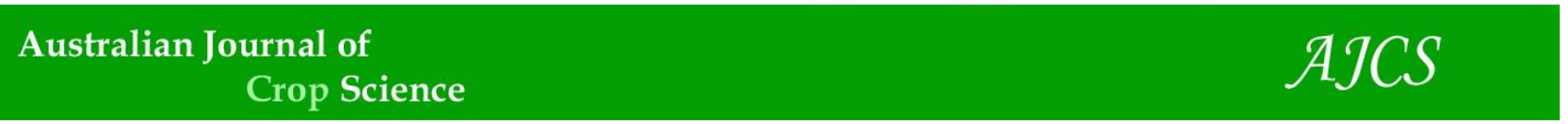

AJCS 14(10):1688-1694 (2020)

ISSN:1835-2707

doi: 10.21475/ajcs.20.14.10.p2811

\title{
Fallow periods on a secondary forest with Platonia insignis Mart. in western
} Brazilian Amazon

\author{
Larissa de Paula Viana da Silva ${ }^{1}$, José Ribamar Gusmão Araujo ${ }^{1}$, Ariadne Enes Rocha ${ }^{2}$, Raudielle Ferreira \\ dos Santos ${ }^{3}$, Wyayran Fernando Sousa Santos ${ }^{1}$, Mário Luiz Ribeiro Mesquita ${ }^{4}$, Francisca Helena Muniz ${ }^{1}$ \\ ${ }^{1}$ Universidade Estadual do Maranhão, Programa de Pós Graduação em Agroecologia, CEP 65055-310, São Luis, \\ Maranhão Brasil \\ ${ }^{2}$ Universidade Estadual do Maranhão, Departamento de Fitotecnia e Fitossanidade CEP 65055-310, São Luis, \\ Maranhão Brasil \\ ${ }^{3}$ Universidade Estadual do Norte Fluminense Darcy Ribeiro, CEP 28.013-602, Campos dos Goitatazes, Rio de Janeiro, \\ Brasil \\ ${ }^{4}$ Universidade Estadual do Maranhão, Programa de Pós Graduação em Agricultura e Ambiente, CEP 65055-310, São \\ Luis, Maranhão Brasil
}

*Corresponding author: mario-mesquita51@hotmail.com

\begin{abstract}
Changes in the structure of the vegetation reflect on the biodiversity and dynamics of the ecosystem. The objective of the study was to characterize and compare the structure of fragments of vegetation with the occurrence of Platonia insiginis, in different stages of regeneration, with 6, 10, 25 and 100 years of fallow period in western Brazilian Amazon. The study was conducted in a completely randomized design, with four treatments, consisting of 6, 10, 25 and 100 years of fallow period, and five replications, consisting of demarcated temporary plots for each fallow period, with dimensions of $2 \mathrm{~m} \times 2 \mathrm{~m}$ for the regenerating stratum of vegetation and $10 \mathrm{~m} \times 10 \mathrm{~m}$ for the adult stratum of vegetation. Phytosociological parameters evaluated were number of individuals and species, total density, total height, stem diameter and Shannon Diversitylndex ( $\left.\mathrm{H}^{\prime}\right)$, Pielou Equability $(\mathrm{J})$ and Jaccard Similarity Index (JSI). The data were subjected to the Analysis of Variance, followed by the Tukey Test $(p<0.05)$ and Principal Component Analysis. There was low species diversity for the sampled areas, with $\left(\mathrm{H}^{\prime}\right)$ rates ranging from 0.65 to 2.46 nats ind ${ }^{-1}$. The vegetation fragments with 100 years of fallow period showed a floristic similarity of $10 \%$ with the others, while those of 6 and 10 years of fallow period, reached similarity of $40 \%$. For the regenerating strata only, the number of individuals and total density differed, with the lowest averages, respectively, of 5 and 1,400 individuals ha ${ }^{-1}$ at 100 years of fallow period. For the adult strata, there was a difference between all parameters corroborating the results obtained in the Principal Component Analysis, at 100 years of fallow period, a lower average was obtained for the number of individuals (7), and higher averages of plant height (22.1 $\mathrm{m}$ ) and diameter at breast height $(36.45 \mathrm{~cm})$. As conclusion, the time required for the complete natural regeneration of secondary vegetation fragments in the Brazilian Amazon is over 100 years.
\end{abstract}

Keywords: Biodiversity; Natural regeneration; State of Maranhão; Succession; Secondary vegetation.

Abreviations: Total height_ALT; Total density_TD; Diameter at breast height_DBH; Diameter at soil level_DSL; Shannon diversity index_H'; Pielou equability index_J; Índice de Jaccard similarity index_JSI; Unidentified species 1_N1; Unidentified species 2_N2; Number of species_NSPP; Number of individuals_NI.

\section{Introduction}

The Amazon biome has approximately 6.9 million $\mathrm{km}^{2}$. It is the largest and most important global biodiversity repository (Cardoso et al., 2017), and is recognized worldwide for providing intangible ecosystem services to humanity and essential to the planet's balance (Castro and Andrade, 2016). However, despite the worldwide relevance, anthropogenic disturbances are constant, particularly the advance of deforestation over primary forest areas and the reduction of years of fallow period over secondary forest formations (Ribeiro Filho et al., 2013). These disturbances have compromised the ecological balance in the Amazon over the years (Andrade et al., 2017).
In general, changes in vegetation structure under the Amazon biome have been reflected in its biodiversity, functioning and dynamics, with potential damage to cultural diversity and local economic sustainability (Zhang et al., 2018). Therefore studies are increasingly needed to understand its conservation and management based on the species ecological importance, their functions and interdependent relationships between individuals during the process of ecological succession (Dionisio et al., 2016).

Dense and diverse natural populations of Platonia insignis Mart. (Clusiaceae), are concentrated in the Western Brazilian Amazon secondary forest in different stages of regeneration. P. insignis is a native forest species of Brazil, 
popularly known as bacurizeiro which has socioeconomic importance particularly between the North and Northeast regions of the country where it is abundant (Pontes et al., 2017). P. insignis fruits are considered noble for their organoleptic characteristics and high nutritional value, which justify the wide market acceptance for both in natura consumption and industrialization (Santos et al., 2019). It is noteworthy that many fruit species have been widely recognized for multifunctionality within agroecosystems, as they simultaneously contribute to farmer income, provide food security, conserve biodiversity and favor ecosystem services (Barrios et al., 2018). In addition, the spontaneous occurrence of potential species in secondary vegetation enables farmers to practice selective mowing, thus enhancing secondary vegetation importance by making it a productive component of the agroecosystem (Souza et al., 2010). Complete regeneration of secondary vegetation occurs in several succession stages, with different floristic and structural compositions and requires long fallow periods for biomass and nutrient accumulation, as well as for recovery of natural soil fertility (Silva et al., 2015). Thus, secondary vegetation from anthropogenic disturbances has been the object of study given the importance of understanding the functioning, dynamics and distribution of plant communities over time and space. In this context, the objective of this study was to characterize and compare the structure of vegetation fragments with the occurrence of Platonia insiginis, under Brazilian Amazon, in different stages of regeneration, with $6,10,25$ and 100 years of fallow period.

\section{Results}

Composition, diversity and floristic similarity of secondary vegetation fragments with Platonia insignis Mart. at different years of fallow period

In total, we identified 363 living individuals. From these, 190 from 50 species and 38 families were observed in the regenerating stratum, and 173 from 37 species and 28 families were recorded in the adult stratum (Table 1). We observed a greater species diversity in the regenerating stratum with 25, 100 and 10 years of fallow period (from now on, YFP), with Shannon Diversity Index ( $\left.\mathrm{H}^{\prime}\right)$ of $2.46 ; 2.36$ and 2.15 nats.ind $^{-1}$ respectively. There was a greater abundance of $P$. insignis individuals in the adult stratum. However, the estimated species density was higher in the regenerating stratum, except for the 100 YFP (Table 2).

Based on the total sampling of 42 species, considering regenerants and adults, there was low floristic similarity between the areas, with the Jaccard Similarity Index (JSI) ranging from 10 to $40 \%$. The 100 YFP was similar in only $10 \%$ to the 6, 10 and 25 YFP, while the younger 6 and 10 YFP were more similar to each other, with $40 \%$ JSI. Despite the different stages of development, the areas with 6, 10 and 25 YFP were grouped and showed a floristic similarity of $30 \%$ (Figure 1).

Effect of years of fallow pereiods on the number of individuals, number of species, total density, total height and stem diameter in secondary vegetation fragments, with occurrence of $P$. insignis
The Principal Component Analysis (PCA) results showed that the total data variation for the attributes number of individuals, number of species, total density, total height, stem diameter at soil level and at breast height is explained in $90.5 \%$ and $85.34 \%$ for the two main components, respectively, for the regenerating (Figure $2 \mathrm{~A}$ ) and adult (Figure 2B) strata of the sampled vegetation fragments.

The PCA also showed the interrelationships between the parameters density, diameter and height for both strata, indicating that sample units with a high number of individuals per area tend to have smaller values of diameter and height. It is also worth highlighting the tendency that the greater the number of individuals sampled, the greater the number of species, until the inflow of new species stabilizes.

For the regeneratoin stratum of the sampled fragments, the PCA showed high values of association between stem diameter and plant height with the $10 \mathrm{YFP}$, while the highest values of number of individuals, density and number of species were associated with the 6 year fallow period. For the adult stratum, high values of diameter and height were associated with the 100 years fallow period, while the highest values of number of individuals, density and number of species were associated with the 25 YFP.

Only the mean values of the parameters number of individuals and total density differed statistically among YFP for the regenerating stratum of vegetation. The lowest averages of these attributes were observed in the 10 and 100 YFP. All evaluated parameters differed statistically between fallow times for the adult vegetation stratum. The highest averages of height $(\mathrm{m})$ and diameter at breast height $(\mathrm{cm})$ were observed in the 100 YFP, but the highest means of number of individuals, total density and number of species were obtained in the 25 YFP (Table 3), in accordance with the trends exposed in the PCA.

\section{Discussion}

Composition, diversity and floristic similarity of secondary vegetation fragments with Platonia insignis Mart

The total number of 363 individuals from 42 species and 24 families in the regenerating and adult strata sampled in 0.2 ha of secondary vegetation in the Brazilian Amazon biome, differed from the values reported in similar research in the same biome. Guimarães et al. (2016), sampled 565 individuals from 74 species and 33 families in a floristic and phytosociological survey in 0.5 ha, with 40 years of abandonment, in the municipality of São Francisco do Iratapuru, state of Amapá, northern Brazil. Similarly, Coelho et al. (2003), identified 487 individuals from 18 species in a 0.04 ha fragment with 4 YFP, 758 individuals from 30 species in 0.12 ha with 8 YFP and 2549 individuals from 73 species in 0.12 ha with 12 YFP.

Variations in the number of individuals, species and families, even under similar types of vegetation cover, may be explained by differences in the floristic composition structure, which is related to the period and management of the sampled fragments. The selective mowing, previously practiced in the $6,10,25$ and $100 \mathrm{YFP}$, contributed to the high abundance of $P$. insignis species, and consequently, to low species diversity in the areas (Table 2 ).

Of the 363 individuals sampled in 0.2 ha of the Brazilian Amozon, 132 (36\%) were identified as $P$. insignis. In contrast, 


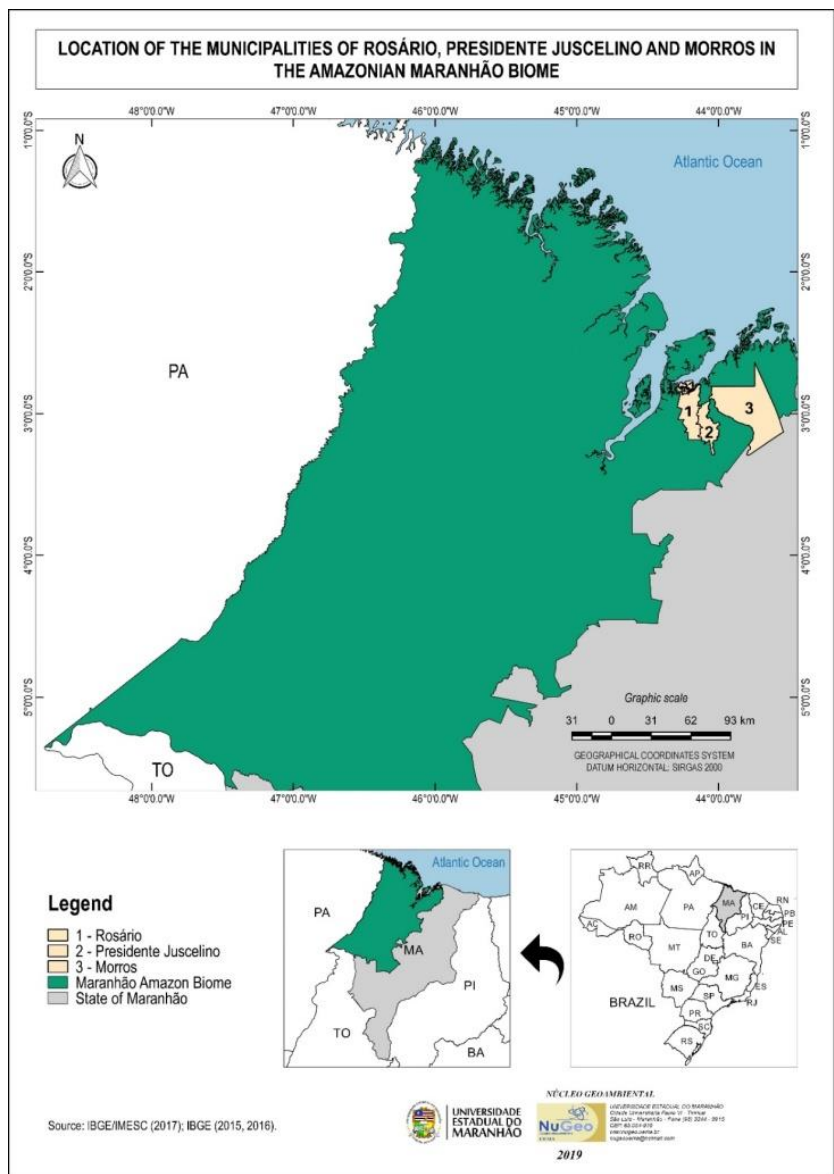

Fig 1. Map of study areas in the state of Maranhão, western Brazilian Amazon.

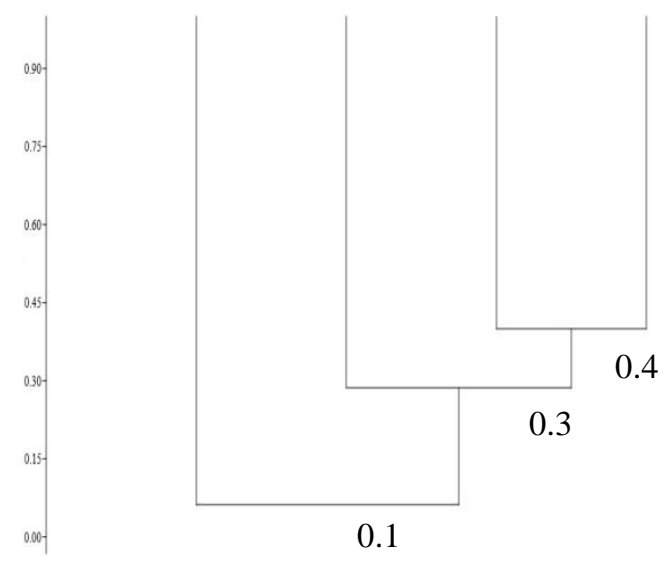

Fig 2. Floristic similarity dendrogram from the Jaccard Diversity Index between the regenerating and adult strata of natural fragments of Platonia insignis Mart., with 6, 10, 25 and 100 years of fallow periods, in the state of Maranhão, western Brazilian Amazon (Cophen. Corr .: 0.99) 

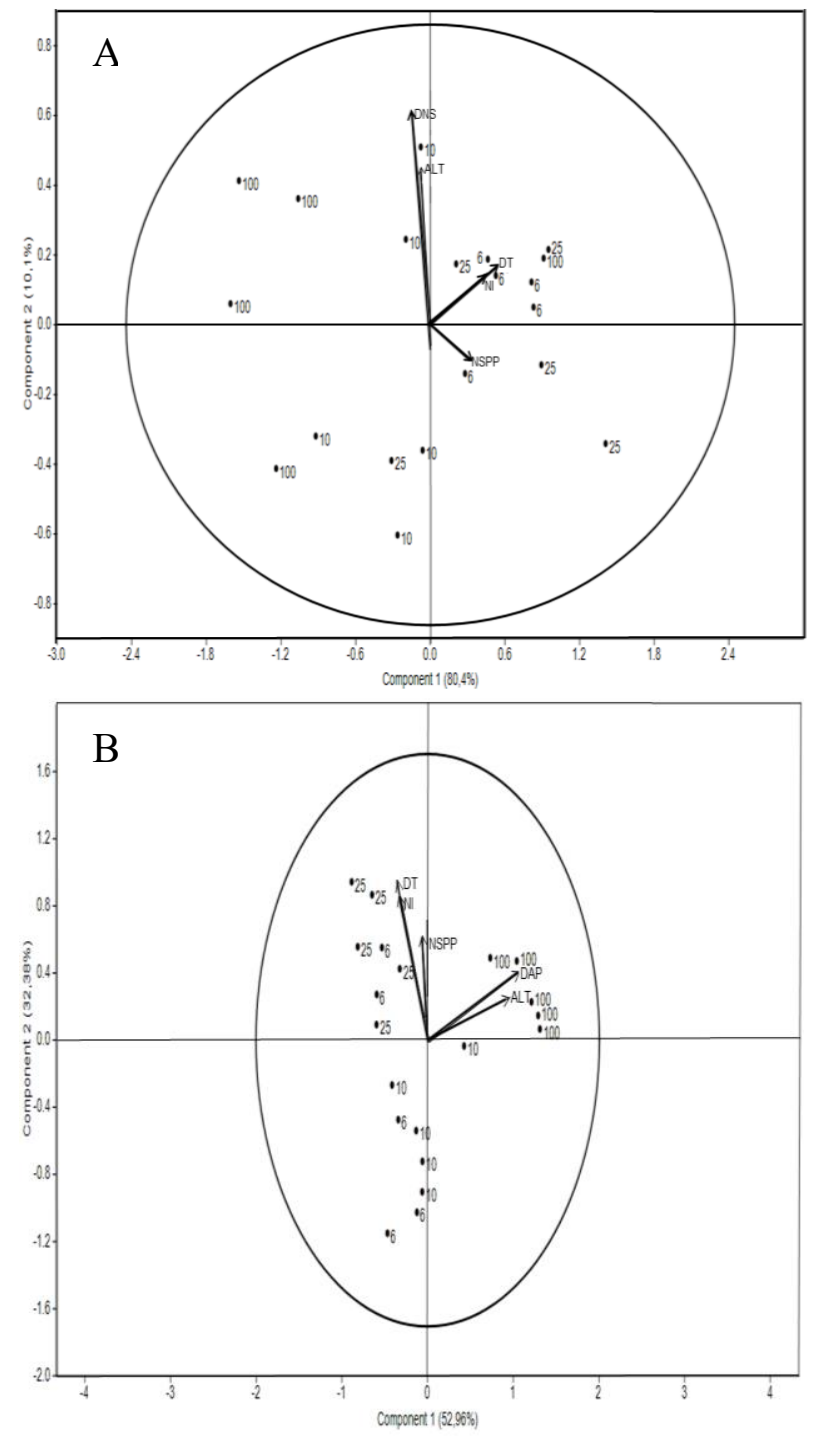

Fig 3. Principal Component Analysis (PCA) of the attributes such as number of individuals (NI), number of species (NSPP), total density (DT), total height (ALT) and diameter at soil level level (DNS) in the regenerating stratum (A) and at breast height (DBH) in the adult stratum (B) of vegetation fragments with Platonia insignis Mart. with 6, 10, 25 and 100-year-old fallows in the state of Maranhão, western Brazilain Amazon.

Table 2. Species diversity and equability; number of individuals, abundance and density estimate of Platonia insignis Mart. in secondary vegetation fragments with 6, 10, 25 and 100-year-old fallows in the state of Maranhão, western Braziliam Amazon Fallow age.

\begin{tabular}{|c|c|c|c|c|c|c|}
\hline \multicolumn{3}{|c|}{ Sampling areas } & \multicolumn{4}{|c|}{ Abundance of $P$. } \\
\hline & & $\mathrm{H}^{\prime}$ & $\mathrm{J}$ & $\mathrm{NI}$ & insignis & P. insignis/ha \\
\hline (years) & $\left(m^{2}\right)$ & (nats ind $^{-1}$ ) & & 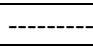 & (------- & \\
\hline \multicolumn{7}{|c|}{ Secondary vegetation regenerating stratum } \\
\hline 6 & 20 & 1.67 & 0.87 & 65 & 31 & 15,500 \\
\hline 10 & 20 & 2.15 & 0.87 & 33 & 2 & 1,000 \\
\hline 25 & 20 & 2.46 & 0.87 & 64 & 9 & 4,500 \\
\hline 100 & 20 & 2.36 & 0.95 & 28 & 0 & 0 \\
\hline \multicolumn{7}{|c|}{ Secondary vegetation adult stratum } \\
\hline 6 & 500 & 1.88 & 0.81 & 37 & 11 & 220 \\
\hline 10 & 500 & 0.65 & 0.47 & 31 & 25 & 500 \\
\hline 25 & 500 & 1.66 & 0.69 & 69 & 35 & 700 \\
\hline 100 & 500 & 1.72 & 0.69 & 36 & 19 & 380 \\
\hline
\end{tabular}


Table 3. Distribution of average values of number of individuals, number of species, total density, total height, stem diameter at soil level in regenerating and adult strata of secondary vegetation fragments with occurrence of Platonia insignis Mart. with 6, 10, 25 and 100 years of fallow period in the state of Maranhão, western Brazilian Amazon.

\begin{tabular}{|c|c|c|c|c|c|}
\hline \multicolumn{6}{|c|}{ Regenerating stratum } \\
\hline \multirow{2}{*}{$\begin{array}{l}\text { Fallow period } \\
\text { (years) }\end{array}$} & $\mathrm{NI}$ & NSPP & TD & ALT & DSL \\
\hline & \multicolumn{2}{|c|}{------------unity---------- } & $\left(\right.$ ind.ha $\left.{ }^{-1}\right)$ & $(\mathrm{m})$ & $(\mathrm{cm})$ \\
\hline 6 & 13 a (2.12) & 4 a (0.89) & 32,500 a $(5,303)$ & 0.9 a $(0.312)$ & $0.8 \mathrm{a}(0.15)$ \\
\hline 10 & $6 \mathrm{~b}(1.82)$ & 4 a (1.00) & $16,500 \mathrm{ab}(4,541)$ & $1.2 \mathrm{a}(0.652)$ & 1 a (0.68) \\
\hline 25 & 12 a (4.32) & 6 a (3.51) & 32,000 a $(10,811)$ & 0.6 a (0.497) & 0.7 a $(0.41)$ \\
\hline 100 & 5 b (5.27) & 3 a $(2.28)$ & 14,000 b $(13,181)$ & 1.6 a $(0.554)$ & 1.7 a (1.02) \\
\hline \multirow[t]{2}{*}{ CV (\%) } & 38.78 & 48.81 & 38.78 & 42.87 & 59.68 \\
\hline & \multicolumn{4}{|c|}{ Adult stratum } & \\
\hline \multirow{2}{*}{$\begin{array}{c}\text { Fallow periods } \\
\text { (years) }\end{array}$} & $\mathrm{NI}$ & NSPP & TD & ALT & DBH \\
\hline & \multicolumn{2}{|c|}{-------------unity----------- } & $\left(\right.$ ind.ha $\left.{ }^{-1}\right)$ & $(\mathrm{m})$ & $(\mathrm{cm})$ \\
\hline 6 & $7 \mathrm{~b}(3.97)$ & $3 a b(1.3)$ & 740 b (397) & $6 \mathrm{~b}(0.912)$ & $9.3 \mathrm{~b}(1.52)$ \\
\hline 10 & $6 \mathrm{~b}(1.3)$ & $2 \mathrm{~b}(0.707)$ & 620 b (130) & $9.8 \mathrm{~b}(3.77)$ & 11.8 b (3.09) \\
\hline 25 & 13 a (3.9) & 4 a (1.67) & 1380 a (390) & 6.7 b (0.385) & $11.07 \mathrm{~b}(3.37)$ \\
\hline 100 & 7 b (1.3) & $3 \mathrm{ab}(1.14)$ & 720 b (130) & 22.1 a (4.66) & 36.45 a (7.59) \\
\hline CV (\%) & 33.9 & 38.03 & 33.9 & 26.69 & 26.18 \\
\hline
\end{tabular}

deviation (SD), CV (\%): coefficient of variation. Means followed by the same letter did not differ statistically by Tukey's test $(p \leq 0.05)$.

Carim et al. (2015) sampled 5,233 individuals in a preserved forest area of 14 ha located at the municipality of Laranjal do Jari, state of Amapá, northern Brazil, and from these, only 24 individuals $(0,45 \%)$, were from of $P$. insignis.

The opposite was observed for species diversity. The Shannon Diversity Index $\left(\mathrm{H}^{\prime}\right)$ values were very low in this study, ranging from 0.65 nats ind $^{-1}$ in the adult stratum with

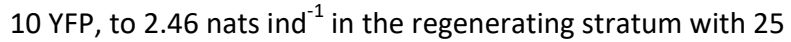
YFP, while Carim et al. (2015) obtained $\mathrm{H}^{\prime}$ of 4.16 nats $^{-1} \mathrm{in}^{-1}$. Few studies have evaluated the regenerating stratum of vegetation fragments due to the difficulty of species identification. However, regarding the floristic diversity, high species diversity is considered for any type and stratum of vegetation when the $H^{\prime}$ values range from 3.83 to 5.85 nats ind $^{-1}$ (Knight, 1975).

The low floristic similarity observed between the secondary vegetation fragments, despite selective mowing management. It may be explained by the different stages of ecological succession of the fragments, since those considered in the initial succession stage, with 6 and 10 YFP, showed higher similarity (JSI $=0.4)$. The high abundance of $P$. insignis, with 113 individuals, (37.79\%) of the 299 individuals sampled between the vegetation strata with 6 and 10 YFP (Table 2) favored the grouping and floristic similarity between the secondary vegetation of these two fallows (ISJ $=0.3$ ).

On the other hand, in addition to the advanced stage of development, the association of higher values of plant height and stem diameter in the adult stratum of vegetation with 100 YFP (Fig. 2) contributed to a lower number of sampling individuals and species, which detracted from the floristic similarity between fallows with younger ages. According to Felfili and Resende (2003), only values above $50 \%$ indicate high similarity. The low floristic similarity between the mid-secondary vegetation fragments, despite selective field management, may be explained by the different stages of ecological succession of the fragments, since those considered in the initial succession stage (6 and 10 YFP), had higher floristic similarity (JSI $=0.4$ ).

Our results corroborate those of Coelho et al. (2003), who also described low similarity between the fragments with 12 and YFP $(50 \%)$, highlighting the greater floristic similarity
(70\%) between the fragments with close in age, 8 and 12 YFP.

Concerning the sampled families in all fallow periods, only Clusiaceae was common to the regenerating and adult strata of the vegetation. This result corroborates other phytosociological studies carried out in secondary vegetation environments under the Amazon biome such as those reported by Coelho et al. (2003), and Guimarães et al. (2016).

Effect of fallow period on the number of individuals, number of species, total density, total plant height and plant diameter, in secondary vegetation fragments, with occurrence of $P$. insignis

According to our results, we infer that fallow period may influence vegetation structure, since the attributes number of individuals (NI), number of species (NSPP), total density (TD), plant height (ALT), stem diamenter at soil level (DSL) and diameter at breast height (DBH) are interrelated (Fig. 2A and $2 \mathrm{~B}$ ) and our research results varied significantly among the years of fallow periods (Table 3 ).

For the regenerating stratum of vegetation, higher means of $\mathrm{NI}$ and TD were obtained with the 6 and 25 YFP. These results are justified by the abundance of natural shoots of $P$. insignis, in the fragment with 6 YFP, with 31 individuals of the species, ( $47.6 \%$ of the 65 individuals sampled). The high occurrence of regenerating individuals in 25 YFP indicates an incomplete regeneration of the fragments and suggests that the areas still receive local management, even with less intensely. For the adult stratum of vegetation, the highest DBH and ALT averages were obtained at 100 YFP, which was expected not only by its fallow period but also by the expressive occurrence of $P$. insignis. The lowest NI and TD averages were observed in the 6, 10 and 100 YFP, corroborating the results obtained by Principal Component Analysis (PCA), which related higher plant heights and stem diameters to the smaller number of individuals and species, and the tendency that the greater the number of individuals sampled the greater the number of species, until the inflow of new species stabilizes. The initial stage of secondary vegetation development of with 6 and 10 YFP justifies the 
lower occurrence of adult individuals in relation to secondary vegetation with 25 YFP (Table 3).

Coelho et al. (2003) exposed the same pattern of influence of fallow period on plant height and stem diameter in the municipality of Bragantina, state of Pará, northern Brazil, even in fragments in the initial succession stage. The authors described mean diameters of $1.3 ; 2.4$ and $2.5 \mathrm{~cm}$ for the 4, 8 and 12 YFP, respectively, and average heights of $1 ; 4.3$ and $4.9 \mathrm{~m}$ for 4,8 and 12 YFP, respectively.

It can be inferred that although the 100 YFP favored the vegetation structure compared to the 6, 10 and 25 YFP, the low species diversity of the oldest fragment (Table 2) indicates that the time required to complete secondary vegetation natural regeneration in the Brazilian Amazon biome is over 100 years.

\section{Materials and methods}

\section{Study site}

The state of Maranhão Amazon biome is located in the Estern Brazilian Amazon. It has a territorial extension of $138.551,765 \mathrm{~km}^{2}$ (Zee-MA, 2019). The climate is sub-humid, with annual average temperature of $27{ }^{\circ} \mathrm{C}$, annual relative humidity of $82 \%$ and rainfall amount varying from 1900 to $2300 \mathrm{~mm}$ per year. There is a predominance of secondary vegetation, Savannah Park, pioneer formation with marine influence and urban influence. The predominant soil classes are Argissol Petric Yellow Red, Quartzarenic Neosol and Yellow Latosol (Nugeo, 2019).

We selected four mid-secondary succession areas in different stages of regeneration in the state of Maranhão Amazon. From these, two were in early stage of succesion. The first, with 6 years of fallow period (from now on, YFP) $\left(02^{\circ} 55^{\prime} 40^{\prime \prime} \mathrm{S}\right.$ and $\left.44^{\circ} 03^{\prime} 54^{\prime \prime} \mathrm{W}\right)$ and the second, with 10 YFP $\left(02^{\circ} 56^{\prime} 04^{\prime \prime} \mathrm{S}\right.$ and 44 o14' 06" W) located the municipalities of Presidente Juscelino and Rosário, respectively and the other two were in advanced stage of succesion, with 25 YFP (02 $\left.51^{\prime} 50^{\prime \prime} \mathrm{S} 44^{\circ} 02^{\prime} 20^{\prime \prime} \mathrm{W}\right)$ and 100 YFP $\left(02^{\circ} 59\right.$ ' $131.8^{\prime \prime} \mathrm{S}$ and $\left.44^{\circ} 05^{\prime} 39.3^{\prime \prime} \mathrm{W}\right)$, located in the municipalities of Morros and Presidente Juscelino, respectively (Fig. 1).

The study areas were selected with the help of local extractivist farmers who practices selective mowing to conserve fruit trees of spontaneous occurrence, particlularly those of $P$. insignis. According to extractivist farmers, they preserve natural sprouts and productive adult trees of this species for consumption and marketing, as an income generation strategy.

\section{Vegetation structure}

The secondary vegetation fragment structure and composition with occurrence of $P$. insignis with the $6,10,25$ and 100 YFP were determined by the plot method, with plot sizes of $10 \mathrm{~m} \times 10 \mathrm{~m}$ for the adult stratum and $2 \mathrm{~m} \times 2 \mathrm{~m}$ to the regenerating stratum. We established five temporary plots for each fallow age. We counted and identified all living individuals within the plots. Thereafter, we measured the stem diameter of the plants at the soil level (DSL) $\leq 5 \mathrm{~cm}$ for the the regenerating stratum, and the diameter at breast height $(\mathrm{DBH}) \geq 5 \mathrm{~cm}$, for the adult stratum.

The phytosociological parameters evaluated were number of individuals, number of species, total height, stem diameter total density, the Shannon Diversity Index $\left(\mathrm{H}^{\prime}\right)$ and the Pielou
(J) Equability Index (Mueller-Dombois \& Ellenberg, 1974). Data processing was performed using the FITOPAC 2.1.2 software (Shepherd, 2009). To verify the floristic similarity between the areas, we used the Jaccard Similarity Index (ISJ), with elaboration of matrices based on the presence and absence of species in the sample units. The resulting floristic similarity matrix was used for cluster analysis by the unweighted arithmetic mean method (UPGMA) and generation of a dendrogram using the $\mathrm{PAST}^{\circledR}$ version 3.11 software (Hammer et al., 2016).

An extractivist farmer contributed with the common name indication of the plant species sampled. The species were identified and pressed to make exsiccates and forwarded to the Rosa Mochel Herbarium, located at the Maranhão State University at São Luís. The classification system adopted for the families and species was the Angiosperm Phylogeny Group IV (APG IV, 2016).

\section{Experimental design and statistical analysis}

The experiment was set up in a randomized complete design, with four treatments represented by the four fallow ages with five replications, totaling 40 sample units. The number of individuals (NI), number of species (NSPP), total density (TD), total height (ALT), stem diameter at soil level (DSL), and stem diameter at breast height (DBH) attributes were evaluated using the Principal Component Analysis (PCA) by the PAST ${ }^{\circledR}$ software version 3.11 (Hammer et al., 2016). Field data were also submitted to Analysis of Variance (ANOVA) and the means were compared by Tukey's test ( $p$ $<0.05)$, using Statistica 7.0 software (Statsoft, 2004).

\section{Conclusions}

The years of fallow period influenced the secondary vegetation composition and structure with occurrence of $P$. insignis in the state of Maranhão, western Brazilian Amazon; however, selective mowing management in the studied fragments contributed to the abundance of $P$. insignis and favored greater floristic similarity between vegetation fragments in early stage of succesion (40\%). The Principal Componente Analysis associated high values of plant height and stem diameter to lower density, as well as high number of individuals to larger number of species per area. The fallow time required for complete natural regeneration of mid-secondary vegetation in the state of Maranhão, western Brazilian Amazon biome is over 100 years.

\section{Aknowledgments}

We thank to Universidade Estadual do Maranhão (UEMA) e to the Programa de Pós Graduação em Agroecologia (PPGA) for the opportunity to do the work. To friends and the Tijupá Agroecological Association, for their help in the field works.

\section{References}

Andrade RTG, Pasini S, Sampaio AF, Ribeiro MS, Cabral GS, Manzatto AG (2017) Fitossociologia de uma floresta de terra firme na Amazônia Sul-Ocidental, Rondônia, Brasil. Biota Amazônia. 7: 36-46.

APG IV (2016). An update of the Angiosperm Phylogeny Group classification for the orders and families of flowering plants: APG IV. Bot J Linn Soc. 181: 1-20 pp. 
Barrios E, Valencia V, Jonsson M, Brauman A, Hairiah K, Mortimer PE (2018) Contribution of trees to the conservation of biodiversity and ecosystem services in agricultural landscapes. Int. J Biodivers Sci Ecosyst Serv Manag. 14: 1-16.

Cardoso D, Sarkinenb T, Alexander S, Amorim AM, Bittrich V, Celis M (2017) Amazon plant diversity revealed by a taxonomically verified species list. P Natl Acad Sci-Biol. 144: 10695- 10700.

Carim MJV, Guimarães JRS, Tostes LCL, Takiyama LR, Wittmann F (2015) Composition, structure and floristic diversity in dense rain forest in the Eastern Amazon, Amapá, Brazil. Acta Sci Biol Sci. 37: 419-426.

Castro AS, Andrade DC (2016) O custo econômico do desmatamento da Floresta Amazônica brasileira (19882014). Perspectiva Econômica. 12: 1-15.

Coelho RFR, Zarin DJ, Miranda IS, Tucker JM (2003) Análise florística e estrutural de uma floresta em diferentes estágios sucessionais no município de Castanhal, Para. Acta Amazon. 33: 563-582.

Dionisio LFS, Filho Bonfim OS, Crivelli BRS, Gomes JP, Oliveira MHS, Carvalho JOP (2016) Importância fitossociológica de um fragmento de floresta ombrófila densa no estado de Roraima, Brasil. Revista Agroambiente. 10: 243-252.

Felfili JM, Resende RP (2003) Conceitos e métodos em fitossociologia. Comunicações Técnicas Florestais. Brasília. 5: 1-68.

Guimarães JRS, Carim MJV, Costa Neto SV, Tostes LCL (2016) Floristic diversity of secondary forest in the eastern amazon, state of Amapá. Floresta. 46: 343-351.

Hammer O, Harper DAT, Ryan PD (2016) PAST: Paleontological Statistics Software Package for Education and Data Analysis. Palaeontol Electron. 4: 1-9.

Knight DH (1975) A phytosociological analysis of species-rich tropical forest on Barro Colorado Island, Panama. Ecol Monogr. 45: 259-28.

Mueller Dombois D, Ellenberg H (1974) Aims and methods of vegetation ecology. p. New York: Willey and Sons. 547p.
NUGEO (2019) Atlas do Maranhão. São Luís, MA: Laboratório de Geoprocessamento/GEPLAN-UEMA. https://www.nugeo.uema.br/?p=11082

Pontes LCG, Moura EF, Moura MF, Rodrigues SM, Oliveira MSP, Carvalho JEU, Therrier J (2017) Molecular characterization of progenies of bacurizeiro (Platonia insignis) from Marajó Island, northeastern Amazon. Acta Amazon. 47: 293-300.

Ribeiro Filho AA, Adams C, Murrieta RSS (2013) The impacts of shifting cultivation on tropical forest soil: a review. Boletim do Museu Paraense Emílio Goeldi 8: 693-927.

Santos RF, Araujo JRG, Neves Júnior ACV, Melo PAFR, Silva LPVS, Santos WFS, Mendes BMM, Rocha AE, Furtado MB, Mesquita MLR (2019) Biometric and Chemical Characterization of Fruits From Selections of Platonia insignis Mart., Native of the State of Maranhão, Brazil. J Agr Sci.11: 376-384.

Silva DV, Oliveira TK, Kusdra JF, Koln FT, Lima AA, Costa KBA (2015) Decomposition of ground biomass of secondary forest and yield of annual crops in no tillage system. Ceres 62: 568-576.

Souza CR, Azevedo CP, Lima RM, Rossi MLB (2010) Comportamento de espécies florestais em plantios a pleno sol e em faixas de enriquecimento de capoeira na Amazônia. Acta Amazon. 40: 127-134.

Shepherd GJ (2009) FITOPAC 2.1.2. Manual do usuário. Campinas: Departamento de Botânica, UNICAMP.

STATSOFT. STATISTICA (Data Analysis Software System) (2004) Version 7. <www.statsoft.com $>$.

Zhang Q, Zhang T, Liu X (2018) Index System to Evaluate the Quarries Ecological Restoration. Sustainability-Basel. 10: 619-629.

ZEE (2019) Zoneamento Ecológico-Econômico do Bioma Amazônia do Maranhão. http://www.zee.ma.gov.br/Portal/relatorios. 